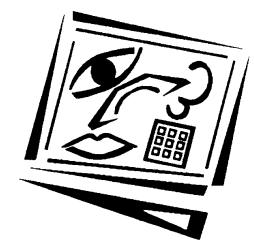

\title{
Planning to teach with digital tools: Introducing the interactive whiteboard to pre-service secondary mathematics teachers
}

\author{
Kathryn Holmes \\ The University of Newcastle
}

\begin{abstract}
Teaching is a complex endeavour that requires teachers to meld knowledge about the nature of learners, pedagogical strategies and discipline content. In recent years an increasing variety of educational technologies are finding their way into the school classroom, including the widespread acceptance of interactive whiteboards (IWBs). The emerging literature on IWB use is mixed, with no clear verdict on the merits of this technology in relation to teaching or student learning outcomes. However, as this equipment is fast becoming standard in a growing number of classrooms, it is important for pre-service teachers to be familiar with its features, potential difficulties and to have had experience in developing lesson activities that utilise the technology.
\end{abstract}

This study examines the lesson activities developed by a group $(n=13)$ of final year undergraduate secondary mathematics pre-service teachers. The analysis is guided by the Technological Pedagogical Content Knowledge (TPCK) framework of Mishra and Koehler (2006). The study reveals that the pre-service teachers were able to plan effectively to integrate IWB features within their mathematical lessons and demonstrated developing TPCK as a result. They found that the primary benefits of the technology related to its potential to engage students with varied visual representations and virtual manipulatives which can aid conceptual understanding.

\section{Introduction}

Like various school systems throughout Australia and the world, the New South Wales public education system is investing heavily in interactive whiteboard (IWB) technology. In 2007, the New South Wales (NSW) state government announced that it would spend A $\$ 66$ million to install interactive whiteboards in all schools by 2011 (NSWDET, 2008). This follows a similar push for technology of this kind in the United Kingdom where many evaluative studies have been carried out (Higgins, Beauchamp \& Miller, 2007). A universal theme emerging from this literature relates to the extent to which teachers are able to adapt their pedagogical approaches to accommodate this new technology in the classroom, in ways that improve student learning. The literature points to the teacher as the critical intermediary in determining the effectiveness of technology use in the classroom and as such, the teachers' familiarity, competence and confidence in relation to IWB use is of paramount importance.

In order for future teachers to be suitably prepared to teach using IWBs, it follows that teacher training should provide pre-service teachers with appropriate learning experiences involving this new technology. This study examines the teaching and learning activities developed by a group of pre-service teachers in their final 
undergraduate year with consideration of the degree to which Technological Pedagogical Content Knowledge (TPCK) is evident (Mishra \& Koehler, 2006). The development of the TPCK framework builds on the earlier work of Shulman (1986) where he described Pedagogical Content Knowledge (PCK) as the intersection between content knowledge and pedagogical knowledge. Specifically, he described it as knowledge of "the most regularly taught topics in one's subject area, the most useful forms of representation of those ideas, the most powerful analogies, illustrations, examples, explanations and demonstrations - in a word, the ways of representing and formulating the subject that make it comprehensible to others" (Shulman, 1986, p. 9).

Mishra and Koehler (2006) have extended Shulman's framework in order to include technology as a significant variable in the current teaching context. They define TPCK as the "basis of good teaching with technology and requires an understanding of the representation of concepts using technologies; pedagogical techniques that use technologies in constructive ways to teach content; knowledge of what makes concepts difficult or easy to learn and how technology can help redress some of the problems students face; knowledge of students' prior knowledge and theories of epistemology; and knowledge of how technologies can be used to build on existing knowledge and to develop new epistemologies or strengthen old ones" (Mishra \& Koehler, 2006, p. 1029). In other words, they emphasise that teachers need to be able to integrate technology with specific content in meaningful ways in order to enhance student learning. It is not sufficient for teachers to be knowledgeable about technology or quality pedagogy, in the absence of knowledge related to how the technology is best used in relation to content knowledge, in order to enable student learning.

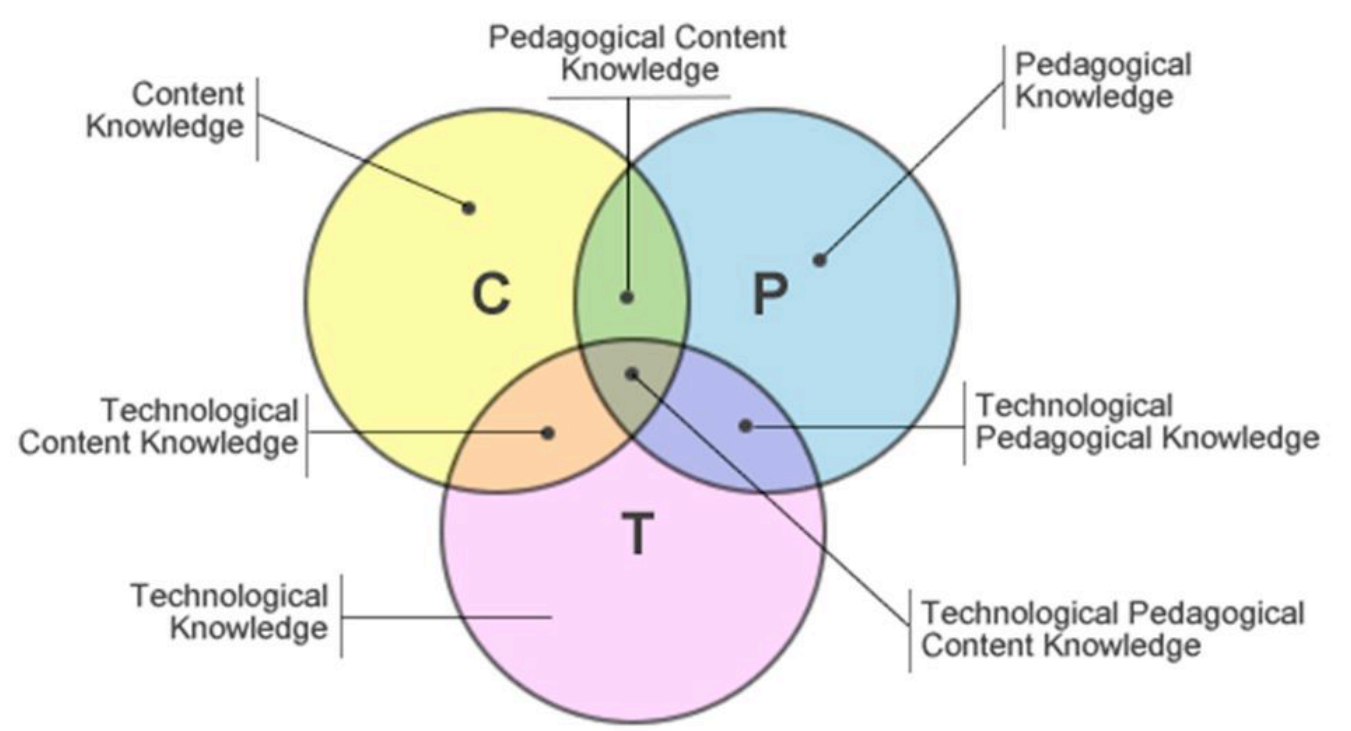

Figure 1: Schematic view of TPCK (Mishra \& Koehler, 2006)

The TPCK model is represented schematically by its authors as the intersection of teacher knowledge about content, pedagogy and technology (Figure 1). Mishra and Koehler (2006) argue that the central construct of TPCK is not merely a straightforward combination of knowledge about content, pedagogy and technology, but rather an emergent form of transformative knowledge that truly integrates the components into 
new forms that have the potential to maximise the effectiveness of educational technology in the classroom. While TPCK is applicable to any educational technology, this study will focus on IWBs and the extent to which pre-service teachers are able to develop teaching and learning activities that demonstrate a careful amalgamation of their knowledge of content, pedagogy and IWB technology. Murcia (2008), working with pre-service science teachers, found that the IWB was a suitable technology through which the creative synthesis of good teaching and learning could occur, while incorporating easy access to a wide variety of science content resources available on the World Wide Web.

\section{Interactive whiteboard (IWB) technology}

Comprehensive reviews of the literature related to the use of IWBs in educational settings have been completed in the UK (Glover, Miller, Averis \& Door, 2005; Higgins, Beauchamp \& Miller, 2007; Smith, Higgins, Wall \& Miller, 2005) and Australia (Schuck \& Kearney, 2007). With regard to their impact on teaching and resultant student learning, Glover et al (2005) point to evidence that the IWB technology can result in enhanced presentations and in the development of student motivation. They also distinguish between teachers with various degrees of competence with IWB technology. Teachers are labelled as 'missioners', 'tentatives' and 'luddites' depending on their capability with and motivation toward the inclusion of technology in their classrooms. While they find evidence that 'missioners' can use the technology to support student learning, they find no evidence that this technological support results in increases in student progress or an improvement in long term achievements.

A similar lack of evidence with regard to student performance is found by Smith et al (2005), who note that the expenditure on IWB technology is being undertaken with little research evidence to justify its cost. They do, however, identify several potential benefits for teachers including greater flexibility and variability, and the ability to deliver multimedia or multimodal presentations with greater efficiency within the presentation due to the touch sensitive screen. In addition, they find that the use of IWBs supports teachers' planning and development of resources, allows teachers to model appropriate ICT skills for the students, and improves interactivity and student participation in lessons. While many potential teaching benefits are identified, Smith et al (2005) also signal some likely problems that may eventuate. Firstly, the lack of adequate training for teachers beyond the initial training by IWB companies and suppliers, and secondly the difficulty of physically placing the IWB in the classroom in order to optimise whole class viewing. Despite these difficulties, the researchers put forward the view that the meaningful combination of technological and pedagogic interactivity holds the most promise for the future of the IWB as a teaching aid. Unlike Mishra and Koehler (2006), they neglect to mention that a deep knowledge of discipline content is also an essential ingredient in the teaching mix.

A further review of the literature was subsequently conducted by Higgins et al (2007), who argue that many of the initial studies related to IWB use in classrooms were somewhat biased as they were generally conducted by fervent 'early adopters' of the technology. However, they do identify various benefits related to the use of IWBs, namely that they are ideally suited to whole class presentations and are able to provide a variety of representations; that IWBs have the potential to cater for a variety of learning styles while addressing some classroom management issues often prevalent when technology is used; that the resources available are better able to capture and 
hold children's attention, thereby leading to an increase in student motivation; that IWB lessons are able to move at an increased pace due to the use of pre-prepared lessons and the ability for teachers to review materials at a later date; and it was found that the IWB was readily adopted by many teachers who might otherwise be reluctant to incorporate technology in any other form. This notion that IWBs are being readily accepted into classrooms was also established by Moss et al. (2007), in a comprehensive evaluative study of IWB use in the UK. Compared to other technologies, the introduction of IWBs is seen by many teachers as acceptable as it does not automatically demand any substantial pedagogical change.

The review by Higgins et al (2007) also identified many drawbacks related to IWB use. Firstly, the cost of installation and maintenance in comparison to other methods of visual display was discussed. It was also noted that initially teachers needed to take considerably more time to prepare lessons, in comparison to the planning required for regular lessons. Higgins et al (2007) reported on some studies indicating that students, at the outset, found some of the IWB lessons confusing, and that rather than introducing greater student interactivity into the lesson, the new technology had actually re-focussed the lesson on the teacher as the centre of the lesson. Lessons that rated most positively were those that reduced the use of the IWB as an interactive interface and instead, used it primarily as a tool for multimedia presentations. Using the IWB in this way, only as a multimedia display tool, has been likened to using it only as an updated 'blackboard' which tends to result in minimal pedagogical changes (Schuck \& Kearney, 2007, 2008), instead of the alternative, which is to see the IWB as a 'gateway for learners to 'reclaim the classroom'; a 'window to the world"(p.72). These sentiments align with the TPACK notion of a 'transformative' learning experience afforded by expert, integrative teacher knowledge.

Although most teachers may be amenable to the presence of an IWB in their classroom, there is evidence that the ways in which the boards are used vary considerably. Glover, Miller, Averis and Door (2007) developed a 'three tier' classification of IWB use within classrooms. In a video study of 50 lessons, they described $28 \%$ of lessons as using a 'supported didactic' teaching approach, which is largely teacher centred; $30 \%$ of the lessons as being 'interactive' at a basic level, and $42 \%$ of lessons as using 'enhanced interactivity', where concept and cognitive development were incorporated in a manner that took full advantage of the interactive nature of the technology. All of the lessons within their study were conducted by teachers who were previously identified as being successful users of IWB technology. The study concluded that good IWB practice was characterised by careful planning prior to the lesson, smooth lesson transitions without interruptions or breaks, a willingness to depart from the lesson script if necessary, use of activities that encourage an active, thinking approach and lessons that have built in mechanisms for immediate feedback to students. The authors also recognised that teaching quality was a key factor in effective IWB use, and that most teachers are yet to achieve the desired level of technological fluency.

The belief that the IWB reinforces traditional, teacher centred pedagogical styles is prevalent in recent literature (Gillen, Staarman, Littleton, Mercer \& Twiner, 2007; Smith, Hardman \& Higgins, 2006; Tanner \& Jones, 2007; Zevenbergen \& Lerman, 2007). Generally, the argument is made that the visual appeal of the IWB focuses the students' attention on the board and on the teacher who generally controls the board (Kennewell, Tanner, Jones \& Beauchamp, 2007). This type of teaching would be classified as 'supported didactic' by Glover et al. (2007), as it does not attempt to 
increase the interactivity of the students within the lesson or to use the full extent of the IWB pedagogical benefits. In addition, in some cases IWB use has been found to reduce the amount of student dialogue occurring in the classroom, possibly as a result of the increased pace of the lesson (Gillen et al., 2007). This increased pace of IWB lessons in comparison to non-IWB lessons was also noted by Smith et al. (2006), who found that student answers to questions were more frequent, but briefer when IWBs were in use. They also found that IWB use led to more whole class teaching and less group work, effectively reducing the role of the student to that of spectator (Jewitt, Moss, \& Cardini, 2007; Reedy, 2008). The possibility of IWB use resulting in passive students learning in traditional transmission mode is at odds with the promise of this new 'interactive' technology.

While there is considerable evidence that lesson interactivity is often decreased through IWB use, there are also some promising studies that point to increases in student engagement. However, the degree to which positive outcomes are achieved depend heavily on individual teachers (Glover et al., 2007). In particular, it has been found that good teachers used a wide variety of resources without significant breaks in the lesson, that they often departed from the 'planned script' to review previous screens, that they managed to keep students on task for most of the lesson by providing clear, visual representations of concepts and activities that incorporated immediate feedback for students (Glover et al., 2007). This ability to increase the availability of visual images in mathematics is important, since 'visualisation' as a key component of mathematical understanding is increasingly being recognised (Arcavi, 2003; Sedig \& Liang, 2006; Sedig \& Sumner, 2006). Furthermore, some teachers have found that the IWB allowed them to be more creative, to build up a valuable collection of easily stored resources, and be able to keep students motivated, interested and focused through a faster flowing lesson (Shenton \& Pagett, 2007). Positive outcomes have been achieved when teachers have been able to incorporate the affordances of the IWB technology into their existing effective pedagogical approaches.

A common theme throughout the IWB literature is that teacher proficiency with the technology is a key factor in determining the effectiveness of its application in classrooms. It has also been found that teachers' own learning experiences with technology is a major determinant of the extent to which they will incorporate technology when teaching (Crison, Lerman \& Winbourne, 2007). It follows, therefore, that it is important for pre-service teachers to be immersed in active learning about technology so that they will draw on this experience when planning to provide an active learning environment for their students. This study examines such a group of pre-service teachers as they grapple with the IWB technology for the first time and attempt to plan learning experiences that will best utilise this digital tool in a secondary mathematics classroom.

\section{Method}

This study examines the assessment tasks of a sample of pre-service teachers $(n=13)$ in their final year of a four year secondary mathematics teaching degree. The preservice teachers were undertaking a compulsory mathematics method course related to the use of technology in the secondary mathematics classroom. At the beginning of the course, the pre-service teachers were asked to write briefly about their existing opinions related to the use of technology in the mathematics classroom. Then, as part of the assessment for the course, they were asked to develop a lesson activity using an 
IWB and its associated presentation software. As part of the course the students were introduced to the technical capability of the IWB and its software and were made cognisant of the literature related to IWB use in school classrooms. The students were expected to draw on their knowledge of theories of quality pedagogy, but were allowed to choose the mathematical content for their activity from any school mathematics content. The students were also asked to justify the design of their learning activities with reference to current pedagogical theories.

In terms of TPCK the study can be represented as in Figure 2. The students were asked to carefully choose mathematics content that could meaningfully be transformed into a lesson activity and that would make use of the IWB and its software. The student teachers were also asked to consider the NSW Quality Teaching Model in their planning, with the aim of maximising their TPCK, thereby producing a quality activity for use in the secondary mathematics classroom. Midway through the course the students were given the opportunity to workshop their ideas with their peers and to make any necessary adjustments.

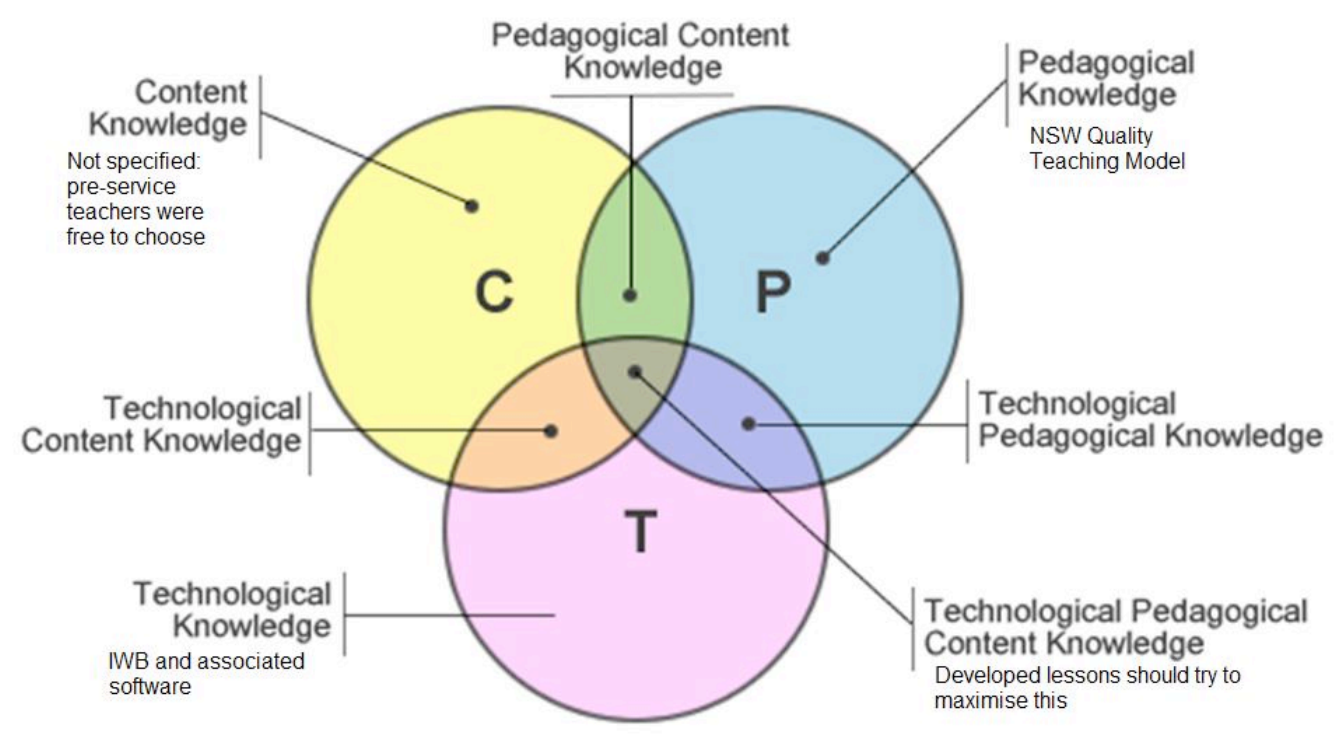

Figure 2: Relationship between course assessment task, NSW Quality Teaching Model and TPCK

\section{Results and discussion}

At the beginning of the mathematics method course the pre-service teachers were asked to respond to an open ended question asking them to express their current opinions related the use of technology in the mathematics classroom. Several themes emerged from their responses. Firstly, there is evidence of the recognition that technology is prevalent throughout society, that students will need technological skills in the future and that current students are using technology in many aspects of their lives, therefore, schooling and learning should reflect similar progress $(n=5)$. 
Technology plays an important role in our society with many aspects of life relying heavily on the use of technology. A person who could not adequately use technology could be disadvantaged (Student 7)

As technology is advancing people are expected to use digital equipment to increase productivity in the workplace. As such it is only natural that students should learn how to use this equipment in their schooling (Student 11)

Secondly, the student teachers demonstrated an understanding that technology is just a tool which can be used to aid the learning process or can interfere with learning if used inappropriately $(\mathrm{n}=10)$.

... providing the students with these (tools) may decrease their development of conceptual knowledge in mathematics (Student 2)

... my first concern is that by increasing technology there will be a reduction in the amount of simple procedures students do. These simple procedures were the foundation of my own understanding (Student 4)

Also, there was evidence of an awareness of the need for schools and teachers to be conscious of the equity issues associated with technology use, particularly with regard to the distribution of resources $(n=4)$.

Allocation of resources may be uneven with some schools or classes with schools being left behind (Student 8)

The equity disadvantage is obvious where there might be some students who do not have access to a computer or relevant technology at home, or are unfamiliar with their use compared to other students (Student 10)

In addition, the pre-service teachers were mindful of the general lack of teacher knowledge with regard to some new technologies $(n=4)$.

Teachers would need to understand why a particular resource is being used and how this will promote learning outcomes (Student 8)

Provided the teacher is knowledgeable in the use of technology and that students use the technology as intended, it will assist student learning (Student 12)

Finally, there was a general recognition of the advantages that are afforded by some technologies, with regard to the ease of availability of multiple representations and the interactivity of the representations of mathematics concepts $(n=9)$

Positive aspects of technology in the classroom include providing visual aids to assist students that have a visual learning style (Student 3)

The main benefit of teaching and learning mathematics with technology is that students gain a deeper understanding since the concepts are presented from multiple perspectives (Student 10)

These responses, given prior to the start of the mathematics method course indicate that the pre-service teachers in the sample were amenable to the suggestions of an increased technological presence in the classroom, but that they were cautious in regard to equity issues. They also recognised that there is a pressing need for teachers to have sufficient knowledge (i.e. TPCK) about how to meaningfully use technology to assist student learning. They were sensitive to the need for teachers to use technology 
only in ways that may potentially enhance student learning, rather than simply using the technology because it is available.

Each pre-service teacher was then asked to choose a section of mathematical content from one of the 7-12 mathematics syllabus documents in NSW and to produce a lesson activity that utilised the IWB and the presentation software associated with it. The students were expected to consider current pedagogical theories and to integrate them and their chosen content with the IWB technology. The students' lesson activities were developed using presentation software purpose built for the IWB. The activities generally consisted of a series of several screens with various interactive elements incorporated throughout. Table 1 provides details of the learning artefacts with regard to the interactive features of the IWB.

Table 1: Characteristics of learning activities developed by pre-service teachers

\begin{tabular}{|c|l|c|c|c|c|c|c|c|c|c|}
\hline \multirow{2}{*}{$\begin{array}{c}\text { Stu- } \\
\text { dent } \\
\text { no. }\end{array}$} & $\begin{array}{c}\text { Mathema- } \\
\text { tical topic }\end{array}$ & $\begin{array}{c}\text { No. of } \\
\text { slides }\end{array}$ & $\begin{array}{c}\text { Col- } \\
\text { our }\end{array}$ & $\begin{array}{c}\text { Hide } \\
\text { and } \\
\text { reveal }\end{array}$ & $\begin{array}{c}\text { Links to } \\
\text { multiple } \\
\text { represen } \\
\text {-tations }\end{array}$ & $\begin{array}{c}\text { Links to } \\
\text { inter- } \\
\text { active } \\
\text { websites }\end{array}$ & $\begin{array}{c}\text { Sort or } \\
\text { slide }\end{array}$ & $\begin{array}{c}\text { Visual } \\
\text { images }\end{array}$ & $\begin{array}{c}\text { Anim- } \\
\text { ations or } \\
\text { Applets }\end{array}$ & $\begin{array}{c}\text { Allow- } \\
\text { ance for } \\
\text { student } \\
\text { annot- } \\
\text { ations }\end{array}$ \\
\hline 1 & Basic algebra & 9 & $\mathrm{X}$ & $\mathrm{X}$ & $\mathrm{X}$ & & & & & \\
\hline 2 & Tessellations & 15 & $\mathrm{X}$ & $\mathrm{X}$ & & & $\mathrm{X}$ & & $\mathrm{X}$ & $\mathrm{X}$ \\
\hline 3 & $\begin{array}{l}\text { Similar } \\
\text { figures }\end{array}$ & 9 & $\mathrm{X}$ & & & & $\mathrm{X}$ & $\mathrm{X}$ & & \\
\hline 4 & $\begin{array}{l}\text { Geometric } \\
\text { series }\end{array}$ & 3 & $\mathrm{X}$ & & & & $\mathrm{X}$ & & & \\
\hline 5 & Surface area & 8 & $\mathrm{X}$ & $\mathrm{X}$ & & $\mathrm{X}$ & & & & \\
\hline 6 & $\begin{array}{l}\text { Factorising } \\
\text { quadratics }\end{array}$ & 5 & $\mathrm{X}$ & & & & $\mathrm{X}$ & & & \\
\hline 7 & $\begin{array}{l}\text { Constructing } \\
\text { triangles }\end{array}$ & 10 & & $\mathrm{X}$ & & $\mathrm{X}$ & & & $\mathrm{X}$ & \\
\hline 8 & Limits & 7 & & & & $\mathrm{X}$ & & & & \\
\hline 9 & Decimals & 1 & & & & $\mathrm{X}$ & $\mathrm{X}$ & & & \\
\hline 10 & $\begin{array}{l}\text { Complex } \\
\text { numbers }\end{array}$ & 3 & & & & & $\mathrm{X}$ & & & \\
\hline 11 & Fractions & 10 & $\mathrm{X}$ & $\mathrm{X}$ & & $\mathrm{X}$ & & & & $\mathrm{X}$ \\
\hline 12 & Circles & 8 & & $\mathrm{X}$ & & & $\mathrm{X}$ & $\mathrm{X}$ & $\mathrm{X}$ & \\
\hline 13 & Probability & 7 & & $\mathrm{X}$ & & & & & $\mathrm{X}$ & $\mathrm{X}$ \\
\hline
\end{tabular}

The most common IWB features employed by the pre-service teachers were the effective use of colour $(n=7)$ to illustrate connections and distinctions between symbols or concepts, the 'hide and reveal' feature $(n=7)$ which enables pre-prepared answers or clues to be revealed immediately and the 'sort or slide' feature $(n=7)$ that allows students to physically touch the screen to manipulate images or symbols. For example, in Figure 3, in a screenshot from Student 12, the hide and reveal feature is used along with an interactive, on screen calculator for students to use. Once the students have attempted the questions on the board, the worked answers can be immediately revealed.

The use of colour and virtual manipulatives was illustrated by student 6 with a lesson on factorisation. In this lesson, algebra tiles can be manipulated on the board to help provide an alternative, visual means of understanding algebraic factorisation. The use 
of colour helps to emphasise the connections between the visual and abstract representations.

\section{Circumference Exercises}

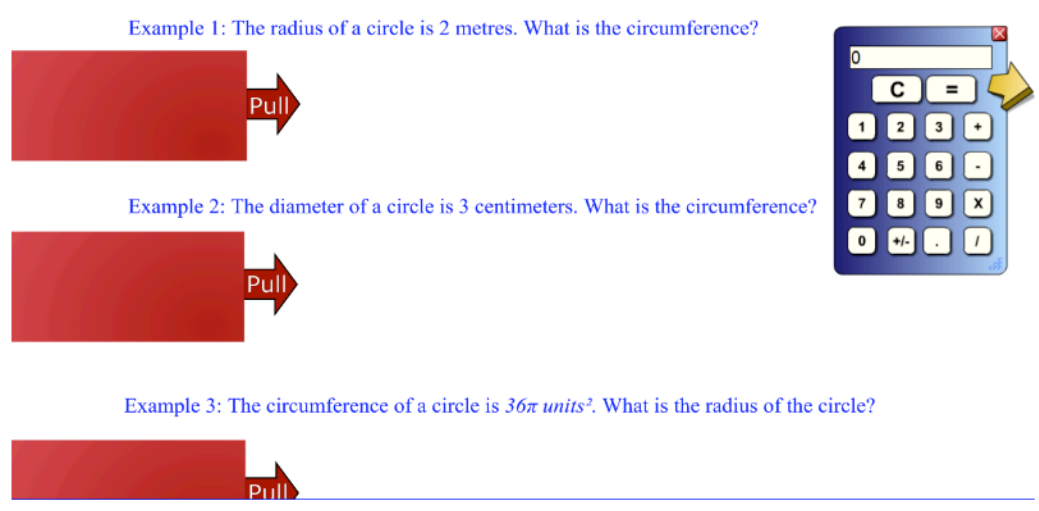

Figure 3: Example page from student activity (student 12)

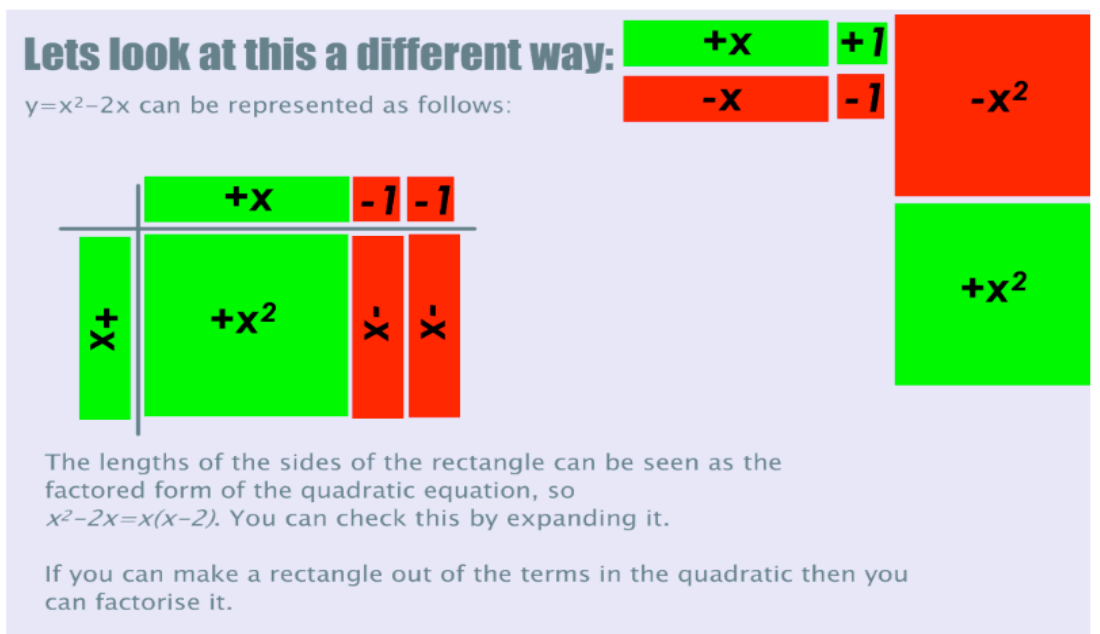

Figure 4: Algebra tile example (student 6)

Student 4 used the concept of decreasing rectangular boxes, which can be moved on the board to illustrate the concept of a limiting sum for geometric series (Figure 5).

Many other students introduced interactivity through the use of hyperlinks to applets on various websites or through the use of the pre-made applets available within the IWB software. In Figure 6, the concept of probability is demonstrated through the use of animated dice which are easily incorporated into the lesson where appropriate. The IWB can then be annotated as the data is collected for a lesson linking theoretical and experimental probability. 


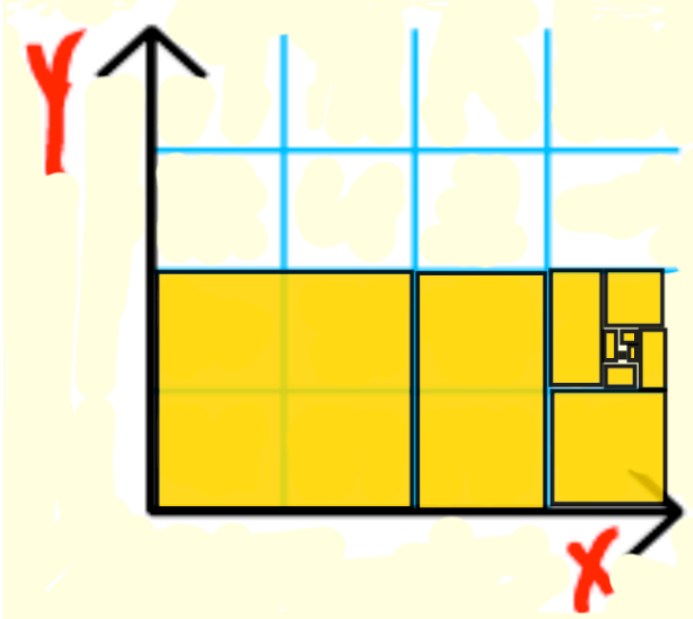

Figure 5: The concept of a limiting sum of a geometric series (Student 4)
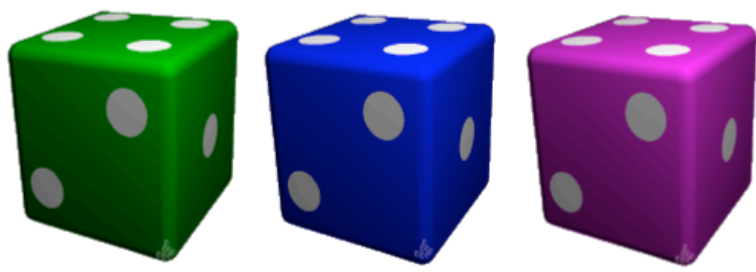
What is the probability of rolling 3 sixes if
three dice are rolled together?

$P(3$ sixes $)=\frac{1}{6} \times \frac{1}{6} \times \frac{1}{6}=\frac{1}{216}$

Will this change is one dice is rolled 3 times?

Figure 6: Animated dice demonstration (Student 13)

Of the mathematics topics chosen by the students, it is interesting to note that only five of the thirteen topics (tessellations, similar figures, surface area, constructing triangles, circles) involve subject matter that would traditionally lend itself to visual representation. The remaining eight topics would traditionally be considered to be heavily symbolic, either numerically or algebraically. However, the lesson activities developed for these topics involved several visual aids such as algebra tiles, colour matched symbols and links to animated applets. While some of these features can be used on a conventional whiteboard, the technology inherent in the IWB makes their inclusion relatively effortless for teachers. Indeed, the ease with which visual images in the form of accurate diagrams, pictures, links to websites and animations can be incorporated may be the dominant transformative feature of the IWB technology. Particularly for mathematics topics that are traditionally presented more abstractedly, 
the use of this technology may signal a pedagogical shift toward teaching styles that more readily acknowledge and use multiple representations. It is generally acknowledged that superior conceptual knowledge is characterised by students that have more than one way of understanding a particular concept (Brenner et al., 1997).

The pre-service teachers were asked to justify their approaches to developing an IWB lesson as part of their assessment for the mathematics methods course. Their responses (summarised in Table 2) indicate that they perceive that the IWB offers many pedagogical benefits for teaching mathematical concepts. Most students mentioned the ease with which visual representations could be incorporated into lessons and that they expected these features to increase students' conceptual understanding.

This lesson gives students another way of factorising quadratic equations with a more concrete representation. This should aid students who may be having conceptual difficulties with other methods (Student 6)

It appears that the availability of alternative forms of representation led the pre-service teachers to consider the pedagogical gains that could be made in terms of developing deeper understanding of the mathematical content under consideration.

The concepts of limits and continuity are difficult for many students to grasp ... the use of this technology provides a level of engagement that otherwise may be difficult to facilitate (Student 8)

Table 2: Pre-service teachers' perceptions of the pedagogical benefits of their IWB lessons

\begin{tabular}{|c|c|c|c|c|c|c|c|}
\hline \multirow[b]{2}{*}{$\begin{array}{c}\text { Stu- } \\
\text { dent } \\
\text { no. }\end{array}$} & \multirow[b]{2}{*}{$\begin{array}{l}\text { Mathem- } \\
\text { atical topic }\end{array}$} & \multicolumn{6}{|c|}{ IWB lesson pedagogical features } \\
\hline & & $\begin{array}{l}\text { Increased } \\
\text { student } \\
\text { engagem- } \\
\text { ent due to } \\
\text { visual } \\
\text { medium }\end{array}$ & $\begin{array}{l}\text { Increased } \\
\text { student } \\
\text { engagement } \\
\text { due to } \\
\text { interaction } \\
\text { with virtual } \\
\text { manipulat- } \\
\text { ives }\end{array}$ & $\begin{array}{l}\text { Promotes } \\
\text { conceptual } \\
\text { understand- } \\
\text { ing through } \\
\text { multiple } \\
\text { represent- } \\
\text { ations }\end{array}$ & $\begin{array}{l}\text { Increases } \\
\text { students' } \\
\text { compet- } \\
\text { ence with } \\
\text { technology }\end{array}$ & $\begin{array}{l}\text { Allows } \\
\text { teachers to } \\
\text { prepare } \\
\text { materials in } \\
\text { advance and } \\
\text { increase } \\
\text { interaction } \\
\text { with class }\end{array}$ & $\begin{array}{l}\text { Allows } \\
\text { teachers } \\
\text { to build } \\
\text { up a } \\
\text { usable } \\
\text { database } \\
\text { of } \\
\text { materials }\end{array}$ \\
\hline 1 & Basic algebra & $X$ & $X$ & $X$ & & & \\
\hline 2 & Tessellations & $X$ & $X$ & $X$ & & & \\
\hline 3 & $\begin{array}{l}\text { Similar } \\
\text { figures }\end{array}$ & $X$ & $\mathrm{X}$ & & $\mathrm{X}$ & & \\
\hline 4 & $\begin{array}{l}\text { Geometric } \\
\text { series }\end{array}$ & $X$ & $\mathrm{X}$ & $X$ & & $X$ & \\
\hline 5 & Surface area & $X$ & $X$ & $X$ & & & $\mathrm{X}$ \\
\hline 6 & $\begin{array}{l}\text { Factorising } \\
\text { quadratics }\end{array}$ & $X$ & $X$ & $\mathrm{X}$ & & & \\
\hline 7 & $\begin{array}{l}\text { Constructing } \\
\text { triangles }\end{array}$ & & $\mathrm{X}$ & $\mathrm{X}$ & & $X$ & $X$ \\
\hline 8 & Limits & $X$ & $X$ & $X$ & & & \\
\hline $9^{*}$ & Decimals & & & & & & \\
\hline 10 & $\begin{array}{l}\text { Complex } \\
\text { numbers }\end{array}$ & $X$ & $\mathrm{X}$ & $\mathrm{X}$ & & & \\
\hline 11 & Fractions & $X$ & $X$ & & & & \\
\hline 12 & Circles & $X$ & & & & $X$ & $X$ \\
\hline 13 & Probability & $X$ & $X$ & & & & $\mathrm{X}$ \\
\hline
\end{tabular}

* Student 9 did not complete this task 
In this sense the students were actively developing their TPCK as they carefully considered the ways in which the IWB technology can be used to not only engage students but also to improve their conceptual understanding.

The time-saving capability of the IWB was also recognised. In particular the students came to appreciate the organisational potential of the software and the ease with which material can be reviewed and accessed time and time again.

I guess gradually over time...you'll build up an effective way to use them, know when to use them and also build a database of files that you can adapt and reuse all the time (Student 13)

Data on the interactive whiteboards can be saved or printed and importantly accessed again for later review (Student 5)

Also, the value of the board in terms of classroom management and teacher-student interactions was noted.

The ability to both type and prepare board work means that the teacher doesn't need to have their back to the audience and can focus on helping students and gives them a chance to walk around the room (Student 4)

Many of the students noted the IWB's potential to engage students with its interactive features.

The IWB offers the benefit that objects can be moved around on the board ... creating interest in the information presented (Student 10)

However, caution was expressed in relation to the overuse of the IWB as the 'novelty' of the technology may decrease over time.

Replacing repetitive chalk and talk lessons with repetitive interactive lessons will cause students to disengage with learning (Student 7).

These remarks also point to the consideration of issues related to the effective incorporation of technology into the classroom, a key component of emergent TPCK. In general the students' explanations provide support for the conjecture that they are aware of the complexity involved when planning potentially effective IWB learning activities.

\section{Conclusion}

It is difficult to assess pre-service teacher's level of TPCK through their responses to one assessment task, as a large portion of a teachers' TPCK is only evident in the classroom when interaction with students is happening. However, particularly when technology is involved, a large part of planning for teaching must occur prior to the learning episode. Mishra and Koehler's (2006) framework provides a simple, diagrammatic representation of the complex interaction between a teachers' content knowledge, pedagogical models and technological expertise. However, the synthesis of the three elements is not straight forward. To use a mathematical analogy, TPCK is not a simple addition of content, pedagogy and technology. The ways in which the three components combine are potentially unlimited depending upon the teachers' underlying competence, confidence and beliefs in relation to the subject they are teaching. 
The results of this small scale study indicate that all of the pre-service teachers were capable of incorporating the interactive features of the IWB to varying degrees. In other words, they became technically competent. Many of them were also alert to the difficulties involved in creating lesson activities designed to optimise the likely benefits of the IWB, while minimising the probable pitfalls. Interestingly, the intrinsic 'visual' nature of the IWB technology motivated the pre-service teachers to produce lesson activities intended to promote a deep conceptual understanding through exposure to varied representations of traditionally abstract ideas. The IWB removes the need for teachers to be able to write and draw clearly on the board, thereby allowing all teachers to present clear, unambiguous diagrams and examples. In addition, the IWB functionality which allows animations and links to websites was perceived as beneficial by the pre-service teachers.

Overall, the students in this study perceived that the main benefits of the IWB technology relate to its visual nature, its interactive features and the ease with which multiple representations of mathematical ideas can be used to promote increased conceptual understanding. However, they were also aware of potential problems associated with the overuse of the IWB and the need for teachers to carefully consider when it is an appropriate learning tool and when other methods might be superior. These considerations indicate that the pre-service teachers were integrating their knowledge of mathematical content, pedagogy and technology, in the manner described by Mishra and Koehler (2006).

While it is clear that the TPCK framework accurately describes the various components for an effective technology based lesson, it is salient to note that good cooking rarely results from equal proportions of all ingredients. Indeed, mathematics educators responsible for educating future teachers should carefully consider the framework when designing teacher training or professional development programs. While the framework identifies the essential components of TPCK, there is no suggested framework for the optimal way to develop this knowledge. For example, should knowledge of content, pedagogy and technology be developed concurrently throughout a teacher training program, or is there an optimal order that will maximise the students' potential to integrate the three components?

In this research the pre-service teachers were in their final year of study when introduced to the IWB as a teaching tool. The students were able to successfully integrate their existing pedagogical and mathematical content knowledge with new knowledge of the IWB technology. However, there could be additional benefits to be gained from introducing the IWB earlier in their undergraduate program. Further research into the development of pre-service teachers' TPCK is required, particularly with regard to the optimal sequencing or amalgamation of undergraduate courses.

\section{References}

Arcavi, A. (2003). The role of visualisation in the learning of mathematics. Educational Studies in Mathematics, 52, 215-241.

Brenner, M., Mayer, R., Moseley, B., Brar, T., Duran, R., Smith Reed, B., et al. (1997). Learning by understanding: The role of multiple representations in learning algebra. American Educational Research Journal, 34, 663-689. 
Crison, C., Lerman, S. \& Winbourne, P. (2007). Mathematics and ICT: A framework for conceptualising secondary school mathematics teachers' classroom practices. Technology, Pedagogy and Education, 16(1), 21-39.

Gillen, J., Staarman, J., Littleton, K., Mercer, N. \& Twiner, A. (2007). A 'learning revolution'? Investigating pedagogic practice around interactive whiteboards in British primary classrooms. Learning, Media and Technology, 32(3), 243-256.

Glover, D., Miller, D., Averis, D. \& Door, V. (2005). The interactive whiteboard: A literature survey. Technology, Pedagogy and Education, 14(2), 155-170.

Glover, D., Miller, D., Averis, D. \& Door, V. (2007). The evolution of an effective pedagogy for teachers using the interactive whiteboard and modern languages: An empirical analysis from the secondary sectors. Learning, Media and Technology, 32(1), 5-20.

Higgins, S., Beauchamp, G. \& Miller, D. (2007). Reviewing the literature on interactive whiteboards. Learning, Media and Technology, 32(3), 213-225.

Jewitt, C., Moss, G., \& Cardini, A. (2007). Pace, interactivity and multimodality in teachers' design of texts for interactive whiteboards in the secondary school classroom. Learning, Media and Technology, 32(3), 303-317.

Kennewell, S., Tanner, H., Jones, S. \& Beauchamp, G. (2007). Analysing the use of interactive technology to implement interactive teaching. Journal of Computer Assisted Learning, 24(1), 6173.

Mishra, P. \& Koehler, M. (2006). Technological pedagogical content knowledge: A framework for teacher knowledge. Teachers College Record, 108(6), 1017-1054. [verified 22 June 2009] http:/ / punya.educ.msu.edu/publications/journal_articles/mishra-koehler-tcr2006.pdf

Moss, G., Jewitt, C., Levaaic, R., Armstrong, V., Cardini, A. \& Castle, F. (2007). The interactive whiteboards, pedagogy and pupil performance evaluation: An evaluation of the Schools Whiteboard expansion (SWE) Project: London Challenge. School of Educational Foundations and Policy Studies, Institute of Education, University of London. [verified 23 June 2009] http:/ / publications.dcsf.gov.uk/eOrderingDownload/RR816\%20Report.pdf

Murcia, K. (2008). Teaching science creatively: Engaging primary teacher education students with interactive whiteboard technology. The International Journal of Interdisciplinary Social Sciences, 3(3), 45-52.

NSWDET (2008). Click: A technology guide for parents [viewed 14 May 2008, verified 23 June 2009] http:/ / www.schools.nsw.edu.au/media/downloads/schoolsweb/news/technology/click.pdf

Reedy, G. B. (2008). PowerPoint, interactive whiteboards, and the visual culture of technology in schools. Technology, Pedagogy and Education, 17(2), 143-162.

Schuck, S. \& Kearney, M. (2007). Exploring pedagogy with interactive whiteboards. [viewed 15 May 2008] http: / / www.ed-dev.uts.edu.au/teachered/ research/iwbproject/home.html

Schuck, S. \& Kearney, M. (2008). Classroom-based use of two educational technologies: A sociocultural perspective. Contemporary Issues in Technology and Teacher Education, 8(4). http: / / www.citejournal.org/vol8/iss4/ currentpractice/article2.cfm

Sedig, K. \& Liang, H. (2006). Interactivity of visual mathematical representations: Factors affecting learning and the cognitive process. Journal of Interactive Learning Research, 17(2), 179212. 
Sedig, K. \& Sumner, M. (2006). Characterizing interaction with visual mathematical representations. International Journal of Computers for Mathematical Learning, 11(1).

Shenton, A. \& Pagett, L. (2007). From 'bored' to screen: The use of the interactive whiteboard for literacy in six primary classrooms. Literacy, 41(3), 129-136.

Shulman, L. (1986). Those who understand: Knowledge growth in teaching. Educational Researcher, 15(2), 4-14.

Smith, F., Hardman, F. \& Higgins, S. (2006). The impact of interactive whiteboards on teacherpupil interaction in the National Literacy and Numeracy Strategies. British Educational Research Journal, 32(3), 443-457.

Smith, H. J., Higgins, S., Wall, K. \& Miller, J. (2005). Interactive whiteboards: Boon or bandwagon? A critical review of the literature. Journal of Computer Assisted Learning, 21, 91101.

Tanner, H. \& Jones, S. (2007). Using video-stimulated reflective dialogue to learn from children about their learning with and without ICT. Technology, Pedagogy and Education, 16(3), 321-335.

Zevenbergen, R. \& Lerman, S. (2007). Pedagogy and interactive whiteboards: Using an activity theory approach to understand tensions in practice. Proceedings 30th Annual Conference of the Mathematical Research Group of Australasia.

http: / / www.merga.net.au/documents/RP812007.pdf

Dr Kathryn Holmes, Senior Lecturer - Mathematics Education

School of Education, Faculty of Education and Arts

University of Newcastle, Callaghan NSW 2308

Email: Kathryn.Holmes@newcastle.edu.au

Web: http: / / www.newcastle.edu.au/school/education/ 